Anna Brzezińska-Rawa

Uniwersytet Mikołaja Kopernika, Toruń

\title{
Zmiana uczestników profesjonalnych po uzyskaniu przez inwestora decyzji \\ o pozwoleniu na budowę w świetle przepisów Prawa budowlanego
}

DOI: http://dx.doi.org/10.12775/SIT.2013.002

\section{Wprowadzenie}

Uczestnikami procesu budowlanego są: inwestor, projektant, kierownik budowy (lub kierownik robót) oraz inspektor nadzoru inwestorskiego. Kwestię pozycji prawnej uczestników tego procesu reguluje Ustawa $z$ dnia 7 lipca 1994 r. Prawo budowlane ${ }^{1}$. Inwestor uzyskuje pozwolenie na budowę, jest stroną w postępowaniu w sprawie jego wydania ${ }^{2}$. Pozostałe podmioty występujące w procesie budowlanym nie mają przymiotu strony, jednakże pełnią istotną rolę. Mianowicie, ich zadaniem jest pomoc inwestorowi w prawidłowym przebiegu procesu budowy. Kierowanie budową i nadzór nad przebiegiem prac budowlanych w sposób profesjonalny leży nie tylko $\mathrm{w}$ interesie inwestora, ale również $\mathrm{w}$ interesie publicznym ${ }^{3}$.

1 T. jedn. Dz.U. z 2010 r. Nr 243, poz. 1623.

${ }^{2}$ Szerzej: W. Szwajdler, Zniesienie instytucji pozwolenia na budowę a prawo zabudowy nieruchomości gruntowych, Torun 2009, s. 86-143; J. Goździewicz-Biechońska, Wadliwość decyzji $w$ procesie inwestycyjno-budowlanym, Warszawa 2011, s. 16-27.

${ }^{3}$ Prawo budowlane. Komentarz, red. T. Asman, J. Dessoulavy-Śliwiński, Z. Niewiadomski, A. Plucińska-Filipowicz,Warszawa 2011, s. 499. 
Kierownik budowy, projektant oraz inspektor nadzoru inwestorskiego muszą legitymować się specjalnymi uprawnieniami do pełnienia samodzielnych funkcji technicznych w budownictwie. Zgodnie $\mathrm{z}$ art. 12 Prawa budowlanego za samodzielną funkcję techniczną w budownictwie uważa się działalność związaną z koniecznością fachowej oceny zjawisk technicznych lub samodzielnego rozwiązania zagadnień architektonicznych i technicznych oraz techniczno-organizacyjnych ${ }^{4}$.

Terminologiczne wyodrębnienie trzech powyższych podmiotów nie jest zadaniem łatwym. Podmiotów tych nie można nazwać łącznie uczestnikami procesu budowlanego, ponieważ pojęcie owych uczestników - jak wskazano - obejmuje również inwestora. $Z$ kolei do osób pełniących samodzielne funkcje techniczne w budownictwie należy również rzeczoznawca majątkowy, jednakże wykonuje on czynności o zupełnie innym charakterze, i - co ważniejsze w omawianym kontekście - nie jest on uczestnikiem procesu budowlanego, więc nie dotyczy go problematyka zmian będąca przedmiotem rozważań niniejszego artykułu.W świetle powyższego można przyjąć konwencję, w myśl której kierownik budowy, projektant oraz inspektor nadzoru inwestorskiego będą nazywani łącznie uczestnikami profesjonalnymi.

Przedmiotem zainteresowania tego artykułu jest problematyka zmiany uczestników profesjonalnych analizowana $z$ punktu widzenia regulacji zawartych w Prawie budowlanym. W związku z powyższym kwestie dotyczące umów zawieranych pomiędzy inwestorem a pozostałymi uczestnikami (np. o kierowanie budową) nie są objęte zakresem tego opracowania. Ponadto zakres tego opracowania obejmuje jedynie czas po wydaniu pozwolenia na budowę, patrząc bowiem przez pryzmat regulacji zawartych w ustawie Prawo budowlane, przed wydaniem pozwolenia jedynym uczestnikiem (poza inwestorem) biorącym aktywny udział w procesie jego uzyskiwania jest projektant, ponieważ do wniosku o jego wydanie należy dołączyć cztery egzemplarze sporządzonego przez niego projektu budowla-

${ }^{4}$ Szerzej: B. Kurzępa, Prawo budowlane. Komentarz do ustawy i orzecznictwo, Toruń 2008, s. 176-194. 
nego ${ }^{5}$. Pozostali dwaj uczestnicy występują dopiero na etapie po wydaniu pozwolenia na budowę.

Problematyka zmiany osób pełniących samodzielne funkcje techniczne $\mathrm{w}$ budownictwie należy, wraz $\mathrm{z}$ problematyką zmiany inwestora, do podmiotowych zmian w procesie inwestycyjno-budowlanym $^{6}$. W celu jej przeanalizowania, w pierwszej kolejności należy określić charakter ich udziału w procesie budowlanym (obligatoryjny czy fakultatywny), zidentyfikować moment powołania tych uczestników oraz, w zakresie niezbędnym do dalszych rozważań, scharakteryzować ich zadania. Powyższe elementy mają bowiem istotny wpływ na proces zmiany uczestnika profesjonalnego.

\section{Charakter prawny uczestnictwa osób będących uczestnikami profesjonalnymi w procesie budowlanym}

Kierownik budowy jest obligatoryjnym uczestnikiem procesu budowlanego w przypadku budowy obiektów budowlanych, na które jest wymagane pozwolenie ${ }^{7}$. Oznacza to, że jego powołanie przez

\footnotetext{
${ }^{5}$ Projekt ten powinien być sporządzony $\mathrm{m}$. in. zgodnie $\mathrm{z}$ zawartą w art. 5 ustawy Prawo budowlane zasadą zgodności projektowania z przepisami, w tym techniczno-budowlanymi, i zasadami wiedzy technicznej. Szerzej: I. Niżnik-Dobosz, Estetyka techniczna i ład przestrzenny jako pojęcia prawa budowlanego oraz prawa planowania i zagospodarowania przestrzeni, w: Przestrzeń i nieruchomości jako przedmiot prawa administracyjnego. Publiczne prawo rzeczowe, red. I. Niżnik-Dobosz, Warszawa 2012, s. 499-502; S. Serafin, Zagadnienia techniczne $w$ prawie budowlanym, Warszawa 2005, s. 60-104; zob. Rozporządzenie Ministra Transportu, Budownictwa i Gospodarki Morskiej z dnia 25 kwietnia 2012 r. w sprawie szczegółowego zakresu i formy projektu budowlanego, Dz.U. z dnia 27 kwietnia 2012 r., poz. 462.

${ }^{6}$ A. Brzezińska-Rawa, Zmiana inwestora po wydaniu decyzji o pozwoleniu na budowę $w$ świetle przepisów prawa budowlanego, „Samorząd Terytorialny” 2012, nr 7-8, s. 161.

${ }^{7}$ Kierownik budowy jest również obligatoryjnie powoływany w przypadku budowy zbiorników na gaz płynny o pojemności do $7 \mathrm{~m}^{3}$, których budowa wymaga zgłoszenia. Jeżeli jest to uzasadnione nieznacznym stopniem skomplikowania robót budowlanych lub innymi ważnymi względami, organ administracji może,
} 
inwestora jest obowiązkowe, a jego zadania obejmują szerokie spektrum czynności zmierzających od zorganizowania budowy przez kierowanie budową takich obiektów w sposób zgodny z projektem i pozwoleniem na budowę, przepisami, w tym techniczno-budowlanymi, oraz przepisami bezpieczeństwa i higieny pracy ${ }^{8}$, aż po czynności zmierzające do oddania obiektu do użytku ${ }^{9}$, co na każdym etapie powinno być dokumentowane w dzienniku budowy. Kwestie te regulowane są w szczególności w art. 22 ust. 2 i 3, art. 42 ust. 2 pkt 1-3 Prawa budowlanego.

Inaczej sytuacja wygląda w przypadku inspektora nadzoru inwestorskiego. Mianowicie uczestnik ten, co do zasady, jest powoływany fakultatywnie, poza dwoma wyjątkami. Pierwszy $z$ nich to sytuacja, gdy obowiązek jego ustanowienia został nałożony przez właściwy organ administracji architektoniczno-budowlanej w decyzji o pozwoleniu na budowę. Stosownie do art. 19 ust. 1 ustawy Prawo budowlane organ może nałożyć tego rodzaju obowiązek w przypadkach uzasadnionych wysokim stopniem skomplikowania obiektu lub przewidywanym wpływem na środowisko. Drugim wyjątkiem od zasady fakultatywności powołania inspektora nadzoru inwestorskiego jest sytuacja, gdy obiekt budowlany należy do obiektów, dla których ustanowienie inspektora nadzoru inwestorskiego jest obowiązkowe, na mocy Rozporządzenia Ministra Infrastruktury z dnia 19 listopada 2001 r. ${ }^{10}$ wydanego na podstawie art. 19 ust. 2 ustawy Prawo budowlane. Stosownie do § 2 ust. 1 tegoż rozporządzenia ustanowienie inspektora nadzoru inwestorskiego jest wymagane przy budowie obiektów budowlanych:

na podstawie art. 42 ust. 3 Prawa budowlanego, wyłączyć, w drodze decyzji, obowiązek powołania kierownika. Wydaje się, że może to nastąpić jedynie w decyzji o pozwoleniu na budowę.

${ }^{8}$ Zob. M. Litwo, E. Kossakowska, Uwarunkowania bezpieczeństwa procesu inwestycyjnego $w$ budownictwie na tle rozwiazań wynikających $z$ różnych gałęzi prawa, w: Przestrzeń i nieruchomości, s. 611-629.

9 J. Goździewicz-Biechońska, op.cit., s. 28.

${ }_{10}$ Rozporządzenie Ministra Infrastruktury z dnia 19 listopada 2001 r. w sprawie rodzajów obiektów budowlanych, przy realizacji których jest wymagane ustanowienie inspektora nadzoru inwestorskiego, Dz.U. z 2001 r. Nr 138, poz. 1554. 
1) użyteczności publicznej i zamieszkania zbiorowego o kubaturze $2500 \mathrm{~m}^{3}$ i większej,

2) wpisanych do rejestru zabytków, w zakresie przebudowy, rozbudowy oraz wykonywania rekonstrukcji lub remontów,

3) niektórych budynków i budowli ${ }^{11}$,

4) budowli mostowych wszelkich typów, w tym wiaduktów, estakad i innych podobnych obiektów budowlanych,

5) zapór ziemnych i wałów przeciwpowodziowych o wysokości $3 \mathrm{~m}$ i większej lub chroniących miasta, wsie, obszary rolne i leśne o powierzchni powyżej 1000 ha oraz budowli technicznych związanych $z$ tymi obiektami budowlanymi,

6) budowli piętrzących o różnicy poziomów lustra wody $3 \mathrm{~m}$ i większej oraz ścian oporowych o wysokości $3 \mathrm{~m}$ i większej,

7) niektórych budowli zbiornikowych naziemnych i podziemnych na materiały stałe, płynne i gazowe ${ }^{12}$,

8) ujęć i przepompowni wód śródlądowych o wydajności powyżej $300 \mathrm{~m}^{3} / \mathrm{h}$ lub głębokości $100 \mathrm{~m}$ i większej,

9) stacji uzdatniania wody i oczyszczania ścieków o wydajności $50 \mathrm{~m}^{3} / \mathrm{h}$ i większej,

10) służących do składowania i usuwania, wykorzystywania lub unieszkodliwiania odpadów,

11) linii elektroenergetycznych o napięciu $110 \mathrm{kV}$ i większym oraz stacji elektroenergetycznych, rozdzielczych i przetwórczych z nimi związanych,

12) linii telekomunikacyjnych przewodowych i radiowych - dalekosiężnych (międzynarodowych, międzymiastowych i wewnątrzstrefowych) oraz linii pomiędzy centralami,

${ }^{11}$ Dotyczy to budynków i budowli: a) o wysokości nad terenem $15 \mathrm{~m}$ i większej, b) zawierających pomieszczenie zagrożone wybuchem w rozumieniu przepisów przeciwpożarowych, c) wymagających uwzględnienia ruchów podłoża, w tym spowodowanych wpływem eksploatacji górniczej, d) z zainstalowaną mocą elektryczną $1000 \mathrm{~kW}$ i większą, e) technicznych o kubaturze ponad $2500 \mathrm{~m}^{3}$, związanych $\mathrm{z}$ obiektami budowlanymi linii telekomunikacyjnych przewodowych i radiowych - dalekosiężnych (międzynarodowych, międzymiastowych i wewnątrzstrefowych) oraz linii pomiędzy centralami.

12 Dotyczy to budowli: a) niebezpiecznych dla ludzi, mienia i środowiska, b) o wysokości lub zagłębieniu $5 \mathrm{~m}$ i większych. 
13) niektórych sieci gazowych ${ }^{13}$,

14) niektórych rurociągów oraz obiektów i urządzeń z nimi związanych $^{14}$,

15) dróg krajowych, wojewódzkich i powiatowych oraz związanych $\mathrm{z}$ nimi bezpośrednio obiektów budowlanych, w tym tuneli drogowych i innych budowli,

16) kanałów żeglugi śródlądowej oraz melioracyjnych,

17) sieci melioracyjnych na obszarze powyżej 100 ha,

18) kanałów energetycznych,

19) dróg szynowych wraz $z$ przeznaczonymi do prowadzenia ruchu budynkami, budowlami i urządzeniami,

20) urządzeń transportowych linowych i linowo-terenowych służących do publicznego przewozu osób w celach turystyczno-sportowych,

21) budowli pola naziemnego ruchu lotniczego na lotniskach.

Ustanowienie inspektora nadzoru inwestorskiego jest wymagane także przy realizacji obiektów budowlanych, niewymienionych powyżej, podlegających ocenie oddziaływania na środowisko, określonych w przepisach o zagospodarowaniu przestrzennym oraz o ochronie i kształtowaniu środowiska.

Natomiast stosownie do § 3 powyższego rozporządzenia ustanowienie inspektora nadzoru inwestorskiego jest wymagane również przy realizacji obiektów budowlanych lub ich części, które zawierają: 1) ustroje konstrukcyjne, takie jak powłoki, łupiny, tarcze, łuki i kopuły oraz linowe wiszące bez względu na ich rozpiętość, a także fundamenty inne niż proste ławy i stopy fundamentowe

${ }^{13}$ Dotyczy to: a) gazociągów o ciśnieniu nominalnym $5 \mathrm{kPa}$ i większym, b) gazociągów o ciśnieniu nominalnym do $5 \mathrm{kPa}$ i średnicach przewodów większych niż $150 \mathrm{~mm}$, z wyjątkiem przyłączy gazowych o ciśnieniu nie większym niż $400 \mathrm{kPa}$, c) obiektów tłoczni gazu, d) obiektów stacji gazowych, wyposażonych co najmniej w dwa ciągi redukcyjne.

${ }^{14}$ Dotyczy to rurociągów oraz obiektów: a) ciepłowniczych: tradycyjnych o średnicy $310 \mathrm{~mm}$ i większej oraz preizolowanych o średnicy $200 \mathrm{~mm}$ i większej, b) wodociągowych o średnicy $200 \mathrm{~mm}$ i większej oraz kanalizacyjnych o średnicy 400 mm i większej, c) innych transportujących czynnik płynny lub gazowy niebezpieczny dla ludzi, mienia i środowiska. 
posadowione bezpośrednio na stabilnym gruncie nośnym, 2) wybrane elementy konstrukcyjne ${ }^{15}$.

W niektórych przypadkach, po uzyskaniu pozwolenia na budowę, projektant nie musi już być aktywnym uczestnikiem procesu budowlanego, co oznacza, że co do zasady jego powołanie jest fakultatywne, zależne od woli inwestora. Jednakże niekiedy aktywność projektanta po uzyskaniu pozwolenia na budowę jest niezbędna. Po uzyskaniu pozwolenia na budowę projektant występuje w następujących sytuacjach:

1) gdy na żądanie inwestora sprawuje nadzór autorski (nadzór nad zgodnością realizacji budowy z projektem);

2) gdy w decyzji o pozwoleniu na budowę organ nałoży na inwestora obowiązek zapewnienia nadzoru autorskiego (art. 19 ust. 1 ustawy Prawo budowlane) - wtedy jego uczestnictwo jest obligatoryjne.

Po wydaniu pozwolenia na budowę w niektórych przypadkach projektant może również występować - w przeciwieństwie do sytuacji wskazanych powyżej - w czynnościach incydentalnych. Przykładowo wtedy, gdy w trakcie budowy (wykonywania robót budowlanych) pojawią się wątpliwości związane $z$ projektem, jest on bowiem zobowiązany do ich wyjaśniania, zgodnie $z$ art. 20 ust. 3 Prawa budowlanego lub w przypadkach odstępstwa od zatwierdzonego projektu budowlanego na podstawie art. 36 lit. a ustawy ${ }^{16}$. Wreszcie projektant sporządza tzw. projekt budowlany zmienny, w szczególności w przypadkach samowoli budowlanej polegającej na wykonywaniu obiektu budowlanego niezgodnie $z$ projektem. Projekt budowlany zamienny, stanowiący odzwierciedlenie stanu faktycznego, jest niezbędnym elementem postępowania legalizacyjnego.

15 Dotyczy to elementów konstrukcyjnych: a) o rozpiętości 12 m i większej, wysięgu $3 \mathrm{~m}$ i większym lub o wysokości jednej kondygnacji $6 \mathrm{~m}$ i większej, b) poddanych obciążeniu użytkowemu $5 \mathrm{kN} / \mathrm{m}^{2}$ i większemu, obciążeniu zmiennemu ruchomemu, a także zwymiarowanych $z$ uwzględnieniem wpływów dynamicznych, termicznych, skurczów materiałowych lub ruchów podpór, c) sprężanych na budowie lub na miejscu ich wbudowania w obiekcie budowlanym, a także poddanych zabezpieczeniu cięgien sprężających i ich urządzeń kotwiących.

${ }^{16}$ Szerzej: A. Ostrowska, Decyzja o zmianie pozwolenia na budowę-uwagi na tle art. 36a Prawa budowlanego, w: Przestrzeń i nieruchomości, s. 531-546. 


\section{Powołanie uczestników profesjonalnych po uzyskaniu pozwolenia na budowę}

Z punktu widzenia Prawa budowlanego moment powołania uczestników profesjonalnych nie jest dowolny. $Z$ brzmienia art. 41 ust. 4 wynika, że powołanie kierownika budowy oraz inspektora nadzoru inwestorskiego przez inwestora musi de facto nastąpić przed złożeniem zawiadomienia o zamierzonym terminie rozpoczęcia robót budowlanych, na których jest wymagane uzyskanie pozwolenia na budowę, do powyższego zawiadomienia należy bowiem dołączyć m.in.: pisemne oświadczenie kierownika budowy (robót) o przyjęciu obowiązku kierowania budową lub robotami budowlanymi, a w przypadku ustanowienia nadzoru inwestorskiego - oświadczenie inspektora nadzoru inwestorskiego o przyjęciu obowiązku pełnienia nadzoru inwestorskiego nad danymi robotami budowlanymi.

Ściślej rzecz ujmując, powołanie przez inwestora kierownika budowy i inspektora nadzoru inwestorskiego następuje w czasie pomiędzy uzyskaniem ostatecznej decyzji o pozwoleniu na budowę a datą co najmniej 7 dni przed rozpoczęciem robót budowlanych, gdyż jest to minimalny czas uprzedniego złożenia zawiadomienia o rozpoczęciu robót budowlanych. I chociaż nie jest wykluczone faktyczne powołanie przez inwestora tych dwóch uczestników wcześniej (przez zawarcie $z$ nimi umowy cywilnoprawnej), to podmioty te - punktu widzenia Prawa budowlanego - uaktywniają się dopiero we wskazanym powyżej momencie.

$\mathrm{Z}$ powołanego wcześniej art. 41 ustawy Prawo budowlane wynika ponadto, że przed rozpoczęciem robót budowlanych należy zawiadomić o zamierzonym terminie ich rozpoczęcia projektanta sprawującego nadzór nad zgodnością realizacji budowy z projektem. W przypadku projektanta termin 7 dni przed rozpoczęciem robót budowlanych to ostateczna data do zobowiązania projektanta do sprawowania tego nadzoru. $Z$ kolei wątpliwości związane $z$ projektem mogą pojawić się na każdym etapie budowy i projektant ma obowiązek ich wyjaśniania. $Z$ brzmienia art. 20 ust. 3 i 4 należy wyprowadzić wniosek, że jest to czynność niezależna od pełnienia funkcji nadzoru autorskiego. 


\section{Regulacja prawna zmiany uczestników profesjonalnych}

Ustawa Prawo budowlane traktuje kwestie zmiany uczestników profesjonalnych $\mathrm{w}$ sposób lakoniczny. Wskazuje ona mianowicie w art. 44, że inwestor jest zobowiązany bezzwłocznie zawiadomić właściwy organ nadzoru budowlanego o zmianie kierownika budowy, projektanta sprawującego nadzór autorski oraz inspektora nadzoru inwestorskiego, równocześnie podając, od kiedy nastąpiła zmiana. Organem właściwym jest ten organ nadzoru budowlanego, do którego należy złożyć zawiadomienie o zamierzonym terminie rozpoczęcia robót budowalnych ${ }^{17}$. Do zawiadomienia musi być dołączone oświadczenie o przejęciu obowiązków przez danego uczestnika profesjonalnego.

Z powyższego wynika, że zawiadomienie powinno zawierać trzy elementy: informację osobową, datę zmiany oraz oświadczenie o przyjęciu obowiązków - brak któregokolwiek z nich spowoduje sformułowanie przez organ nadzoru budowlanego żądania uzupełnienia braków formalnych ${ }^{18}$. Wskazuje się również, że do oświadczenia należy dołączyć zaświadczenie o przynależności do właściwej izby samorządu zawodowego, wyprowadzając ten obowiązek nie $z$ art. 44 ust. 2 Prawa budowlanego, lecz z jego art. 41 ust. $4^{19}$.

Termin złożenia zawiadomienia jest określony przez ustawodawcę jako „bezzwłocznie”. W literaturze przedmiotu wskazuje się, że może być on traktowany na równi z terminem „bez zbędnej zwłoki” przewidzianym w k.p.a. ${ }^{20}$

17 Prawo budowlane. Komentarz, red. A. Despot-Mładanowicz, A. Gliniecki, Z. Kostka, A. Ostrowska, W. Piątek,Warszawa 2012, s. 415.

18 Prawo budowlane,red. T. Asman, J. Dessoulavy-Śliwiński, Z. Niewiadomski, A. Plucińska-Filipowicz, s. 500.

19 B. Bodziony, P. Gniadzik, Prawo budowlane z komentarzem wraz z ustawa o planowaniu i zagospodarowaniu przestrzennym, Warszawa-Jaktorów, s. 216.

${ }^{20}$ Prawo budowlane, red. T. Asman, J. Dessoulavy-Śliwiński, Z. Niewiadomski, A. Plucińska-Filipowicz, s. 499. 
Warto zwrócić uwagę na fakt, że nie zmiana jednego lub nawet wszystkich uczestników profesjonalnych powoduje zmiany treści decyzji o pozwoleniu na budowę. Zmiana treści tej decyzji nie następuje nawet wtedy, gdy ustanowienie tych podmiotów jest obowiązkowe $z$ mocy ustawy lub wynika $z$ decyzji o pozwoleniu na budowę. Wynika to $z$ faktu, że uczestnicy ci nie są imiennie wymienieni w treści powyższej decyzji.

\section{Zmiana kierownika budowy lub kierownika robót}

Zmiana kierownika budowy może nastąpić zarówno przed rozpoczęciem robót budowlanych, jak i po nim, jednakże ta druga możliwość prawdopodobnie zaistnieje w praktyce znacznie częściej, chociażby $z$ powodu źle układającej się współpracy $z$ inwestorem $w$ przypadku budowy tzw. systemem gospodarczym. Może ona również nastąpić w przypadku realizacji budowy tzw. systemem deweloperskim, przy czym najczęściej decyzję w tej kwestii będzie podejmować wykonawca, $z$ którym kierownik budowy ma podpisaną umowę cywilnoprawną. Zauważyć należy, że nawet w drugiej z powyższych sytuacji to na inwestorze ciąży obowiązek zawiadomienia właściwego organu nadzoru budowlanego o zmianie kierownika budowy.

Zmiana kierownika budowy po rozpoczęciu robót budowlanych powinna powodować kontynuację działań poprzedniego kierownika. Jest to oczywiste ze względu na fakt, że niektóre roboty budowlane zostały już dokonane. Nie ulega wątpliwości, że zmiana kierownika budowy, tak zresztą jak pozostałych uczestników procesu budowlanego, powinna znaleźć swoje odzwierciedlenie w dzienniku budowy. Zgodnie $z$ art. 45 ust. 1 ustawy Prawo budowlane dziennik budowy jest dokumentem urzędowym. W literaturze wskazuje się, że status dokumentu urzędowego oznacza nadanie dziennikowi budowy rangi stosunkowo silnego środka dowodowego, ponieważ $z$ dokumentami urzędowymi wiąże się domniemanie prawdziwości ich treści. Jednakże dla zachowania waloru dokumentu urzędowego wymagane jest prowadzenie dziennika budowy w sposób 
zgodny $\mathrm{z}$ zapisami zawartymi w ustawie i akcie wykonawczym ${ }^{21}$. Rozporządzenie Ministra Infrastruktury z dnia 26 czerwca 2002 r. w sprawie dziennika budowy, montażu i rozbiórki tablicy informacyjnej oraz ogłoszenia zawierającego dane dotyczące bezpieczeństwa pracy i ochrony zdrowia ${ }^{22}$,wydane na podstawie delegacji zawartej w art. 45 ust. 4 i 5 Prawa budowlanego, przewiduje w $\S 6$ pkt 3 i 4, że strony dziennika budowy przeznacza się na wpisy dotyczące przebiegu robót budowlanych, a każdy wpis jest oznaczany datą i podpisany przez osobę dokonującą wpisu wraz z podaniem imienia, nazwiska, wykonywanej funkcji i nazwy jednostki organizacyjnej lub organu, który reprezentuje. W myśl § 9 powyższego rozporządzenia do dokonywania wpisów w dzienniku budowy są uprawnieni: inwestor, inspektor nadzoru inwestorskiego, projektant, kierownik budowy, kierownik robót budowlanych, osoby wykonujące czynności geodezyjne na terenie budowy, a także pracownicy organów nadzoru budowlanego i innych organów uprawnionych do kontroli przestrzegania przepisów na budowie - w ramach dokonywania czynności kontrolnych. $Z$ tym że zgodnie z $§ 11$ ust. 2 rozporządzenia za właściwe prowadzenie dziennika budowy, jego stan oraz właściwe przechowywanie na terenie budowy odpowiedzialny jest kierownik budowy.

$Z$ kolei najbardziej interesującym $\mathrm{z}$ punktu widzenia omawianej problematyki jest $\S 6$ ust. 4 ww. rozporządzenia, który przewiduje, że jeżeli w trakcie wykonywania robót budowlanych następuje zmiana kierownika budowy, kierownika robót, inspektora nadzoru inwestorskiego lub projektanta sprawującego nadzór autorski, w dzienniku budowy dokonuje się wpisu określającego stan zaawansowania i zabezpieczenia przekazywanej budowy, rozbiórki lub montażu. Wpis ten potwierdza się datą i podpisami osoby przekazującej i przejmującej obowiązki.

W tym miejscu warto przytoczyć fragment wyroku WSA w Lublinie:

${ }^{21}$ Wyrok WSA w Lublinie $z$ dnia 26 lipca 2011 r., sygn. akt. II SA/Lu 342/11, CBOSA z powołaniem na R. Dziwiński, P. Ziemski, Komentarz do art. 45 ustawy $z$ dnia 7.07.1994r. Prawo budowlane, Lex.

${ }^{22}$ Dz.U. Nr 108, poz. 953 ze zm. 
W przedmiotowym dzienniku budowy brakuje podpisu osoby przekazującej obowiązki kierownika budowy. K. L. - kierownika budowy od 19 czerwca 1998 r. dokonał ostatniego wpisu w dniu 28 kwietnia 2002 r. Z kolejnego zapisu w dzienniku budowy z dnia 17 kwietnia 2004 r. wynikało, że obowiązki kierownika budowy obiektu handlowo-hotelowo-mieszkalnego należącego do W. i T. C. przejął M. W., który wskazał stan zawansowania robót i potwierdził zapis swoim podpisem (k. 14-15 akt administracyjnych). Jednak wpis ten nie został potwierdzony podpisem osoby przekazującej te obowiązki, co stanowi, że dziennik zawiera braki, które powodują, że traci on walor dokumentu urzędowego ${ }^{23}$.

\section{Zmiana projektanta}

O zmianie projektanta jako uczestnika procesu budowlanego można mówić jedynie wtedy, gdy projektant sprawuje nadzór autorski (nadzór nad zgodnością realizacji budowy z projektem), gdyż niezależnie od okoliczności faktycznych osoba projektanta, niezależnie czy autora projektu, czy dokonującego adaptacji projektu gotowego, nie ulegnie już zmianie, ponieważ zarówno projektowanie, jak i adaptacja projektu są czynnościami następującymi przed wydaniem pozwolenia na budowę. $Z$ kolei w przypadkach czynności incydentalnych zmiana projektanta będzie raczej następowała niezwykle rzadko, lub - tak jak w razie czynności wyjaśniania wątpliwości związanych z projektem - wcale. Podkreślenia wymaga fakt, że zawiadomienie organu nadzoru budowlanego o zmianie projektanta dotyczy tylko projektanta sprawującego nadzór autorski (nadzór nad zgodnością realizacji budowy $z$ projektem).

Technicznie rzecz ujmując, zakres obu wymienionych rodzajów czynności jest zbliżony, nadzór autorski obejmuje - oprócz stwierdzania zgodności realizacji robót budowlanych $z$ projektem - również uzgadnianie możliwości wprowadzenia rozwiązań zamiennych $\mathrm{w}$ stosunku do tych przewidzianych $\mathrm{w}$ projekcie. $Z$ punktu widzenia tego opracowania istotna jest - $\mathrm{w}$ świetle uwag dotyczących czyn-

${ }^{23}$ Wyrok WSA w Lublinie $z$ dnia 26 lipca 2011 r., sygn. akt. II SA/Lu 342/11, CBOSA. 
ności incydentalnych - funkcja stwierdzania zgodności realizacji robót budowlanych z projektem. Ustawodawca zdaje się posługiwać tymi terminami zamiennie (zob. art. 41 ust. 4 pkt 1 i 44 Prawa budowlanego). Warto zauważyć, że projektant nie może odmówić pełnienia tej funkcji ${ }^{24}$.

Za dopuszczalną należy oczywiście uznać zmianę projektanta sprawującego nadzór nad zgodnością realizacji budowy z projektem jako część nadzoru autorskiego w trakcie realizacji budowy. Trzeba zauważyć, że - nie rozstrzygając dylematu, czy nadzór autorski może sprawować osoba niebędąca autorem projektu ${ }^{25}$ - może ona na pewno nastąpić wtedy, gdy było kilku projektantów danego obiektu, a jeden $z$ nich został po uzyskaniu pozwolenia na budowę zobowiązany do pełnienia nadzoru autorskiego.

\section{Zmiana inspektora nadzoru inwestorskiego}

Inspektor nadzoru inwestorskiego, którego głównym zadaniem jest reprezentowanie inwestora na budowie, również może zostać zmieniony. Od momentu wpisu do dziennika budowy o zmianie inspektora nadzoru inwestorskiego to nowemu inspektorowi przysługują wszystkie prawa i to na nowym inspektorze ciążą wszelkie obowiązki przewidziane ustawą Prawo budowlane.

\section{Uwagi końcowe}

Na zakończenie warto zwrócić uwagę na problematykę kontynuacji czasowej w pełnieniu swoich funkcji przez poszczególnych uczestników profesjonalnych. W tym zakresie warto zwrócić uwagę na wyrok WSA w Warszawie $z$ dnia 30 listopada 2005 r., w którym sąd ten stwierdza, że:

${ }^{24}$ Odmowa pełnienia nadzoru autorskiego przez projektanta naraża go to na odpowiedzialność zawodową.

${ }^{25}$ Kwestia ta jest indyferentna $z$ punktu widzenia omawianej problematyki. 
Ustanowienie nadzoru autorskiego jest czynnością obejmującą całość inwestycji. Jeżeli w pozwoleniu budowlanym zamieszczono warunek dotyczący obowiązków inwestora w zakresie ustanowienia kierownika budowy, inspektora nadzoru czy nadzoru autorskiego, to każdy z tych podmiotów ma przypisaną przez prawo konkretną rolę do wypełnienia w procesie inwestycyjnym. Prawo nie dopuszcza w ogóle możliwości zaprzestania pełnienia nałożonych obowiązków, w tym pełnienia nadzoru autorskiego. Z art. 44 pkt 3 Prawa budowlanego wynika, że może zmienić się tylko osoba pełniąca taką funkcję, do obowiązków inwestora należy zaś zawiadomienie o takiej zmianie i dołączenia stosownego oświadczenia. Jak z powyższego wynika, dla wypełnienia tego obowiązku bez znaczenia jest w jakiej fazie znajduje się budowany obiekt a także jaki zakres prac na budowie już wykonano. Ze względu na wagę pełnionych w procesie inwestycyjnym funkcji i prawnych celów ustanowienia nadzoru autorskiego, nie można uznać niewykonania warunków pozwolenia w tym zakresie za nieistotne odstąpienie od jego warunków. W żadnym też razie nie stoi na przeszkodzie tej ocenie treść art. 36a ust. 5 Prawa budowlanego, który jedynie wyklucza możliwość uznania za odstąpienie nieistotne, gdy w sprawie wystąpią wymienione tam okoliczności. Nie oznacza to jednak, że inne niewymienione tam okoliczności nie mogą być zaliczone do kategorii istotnego odstąpienia od warunków określonych w pozwoleniu budowlanym ${ }^{26}$.

Z powyższego wynika, że kierownik budowy, inspektor nadzoru inwestorskiego oraz projektant sprawujący nadzór autorski (nad zgodnością realizacji budowy z projektem) pełnią swoją funkcję do momentu oddania obiektu budowlanego do użytku bądź ich zmiany w trybie art. 43. I nie ma tu rozróżnienia ze względu na charakter powołania danego uczestnika (obligatoryjny czy fakultatywny, zależny od woli inwestora). O ile kontynuacja pełnienia funkcji w przypadku uczestnictwa obligatoryjnego jest w pełni uzasadniona, o tyle można zastanowić się nad zasadnością konieczności tej kontynuacji w przypadku fakultatywnego nadzoru sprawowanego przez projektanta bądź inspektora nadzoru inwestorskiego. Z przepisów

${ }^{26}$ Wyrok WSA w Warszawie $z$ dnia 30 listopada 2005 r., sygn. akt VII SA/ /Wa 641/05,LEX nr 214365. 
ustawy, a także $z$ powyższego wyroku wynika, że nie jest możliwe ustanowienie tych uczestników do poszczególnych czynności (np. tylko robót ziemnych). I chociaż możliwe jest zawarcie w tym zakresie umowy cywilnoprawnej, podmioty działające na podstawie takiej umowy będą pozbawione statusu uczestnika profesjonalnego, i co za tym idzie - uprawnień z tym związanych, a zwłaszcza prawa wpisu do dziennika budowy.

Warto również poruszyć kwestię skutków prawnych w przypadku braku zawiadomienia o zmianie uczestnika profesjonalnego. Mianowicie, co wynika $z$ ustaleń WSA, prowadzenie robót budowalnych bez kierownika budowy, obligatoryjnego nadzoru inwestorskiego bądź autorskiego oznacza istotne odstąpienie od warunków pozwolenia na budowę (art. 36 lit. a ustawy Prawo budowlane). Powoduje to uruchomienie przez organ nadzoru budowlanego postępowania w trybie art. 50 i 51 Prawa budowlanego, a także wydaniem decyzji o uchyleniu pozwolenia na budowę ${ }^{27}$. Ponadto prowadzenie robót budowlanych w sposób odbiegający od ustaleń i warunków określonych w pozwoleniu na budowę podlega, zgodnie $z$ art. 93 pkt 4, karze grzywny. $Z$ kolei brak zawiadomienia o zmianach uczestników profesjonalnych naraża inwestora na odpowiedzialność za wykroczenie określone w art. 93 pkt 4 Prawa budowlanego, za które również może być wymierzona grzywna.

\section{SUMMARY}

Changing the professional participants after obtaining a construction permit by the investor under the provisions of the Construction Law

The construction permit allows the investor to carry out the construction works. The investor might not have expertise in the field ofconstruction, therefore during the process of building professionals are appointed and they become official participants of it. They include: construction manager, supervisor and designer, whose task, in general, is to help the investor. Their occurrence after the release of a building permit may be due to construction

${ }^{27}$ B. Bodziony, P. Gniadzik, op.cit., s. 102. 
law, administrative decision - building permit, or be dependenton the will of the investor. The purpose of this article is to analyse the methods and relevant provisions, which allow the above mentioned participants to be changed, following the issue of the decision of the building permit, with particular emphasis on the time aspects of continuation of the functions exercised by them. At the end ofthe article legal effectsof no notice of change of a professional participant are indicated.

Keywords: construction law, participants of construction process. 